DOI $10.31162 / 2618-9569-2019-12-2-540-556$

УдК 297.17

ملخص البحث: للقر اعة أهمية عظمى في حياة الإنسان، ومن ثم كانت الأمر الأول لنبي الله (عليه الصلاة

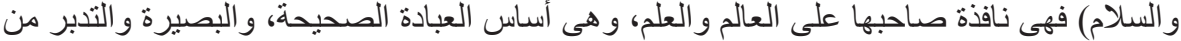

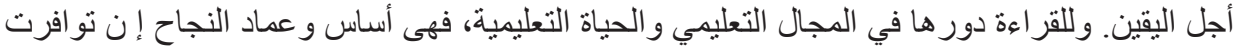

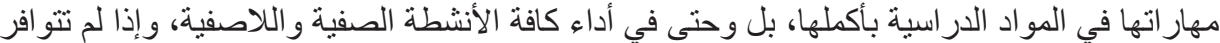

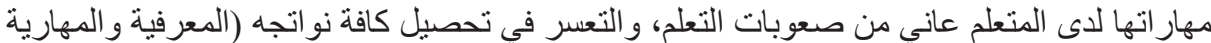

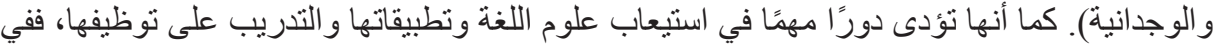

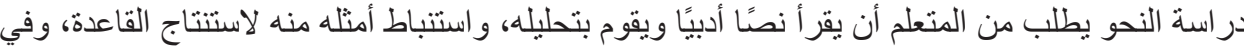

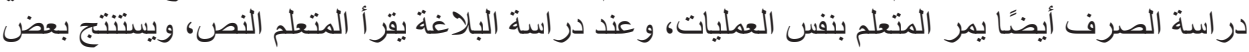

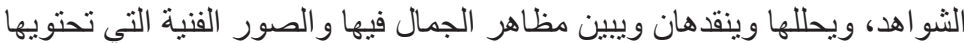

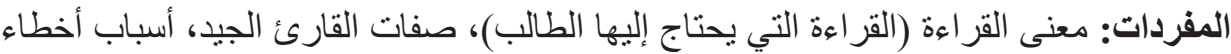

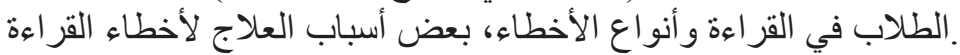

\title{
The Phenomenon of Reading and Knowledge
}

\section{H. M. Bolbol}

Bulgarian Islamic Academy, Bolgar, Russian Federation

ORCID: https://orcid.org/0000-0002-6642-5381,e-mail:bulbul.ismail@mail.ru

Abstract: the article deals with the Muslim view on reading and its role in the intellectual and practical life of humans. The author provides an analysis of the theological perception of this skill. He stresses the fact that that reading opens the "door of knowledge". In its turn, the phenomenon of knowledge and its boundaries is one of the most important categories in Muslim epistemology. Therefore, the author considers the phenomenon of reading and

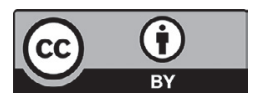

Контент доступен под лицензией Creative Commons Attribution 4.0 License.

This work is licensed under a Creative Commons Attribution 4.0 License.

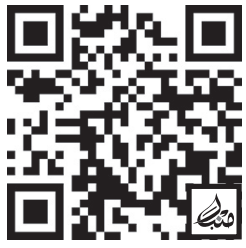


its importance in the study and further development of such disciplines as linguistics, literature, rhetoric. Adequate understanding of the text by its recipient is not always a straightforward process. Therefore, the potential mistakes, which emerge during this process as well as the ways of their rectification receive a detailed analysis and subsequent recommendations.

Keywords: reading, errors of; reading, psychology of; reading, Qur'an on; reading, recipient of; reading, Sunna on; reading, values of

For citation: Bolbol I. H. M. The Phenomenon of Reading and Knowledge. Minbar. Islamic Studies. 2019;12(2):540-556. (In Arabic) DOI: 10.31162/2618-9569-2019-12-2-540-556.

\section{Феномен чтения и знание}

\section{И. Х. М. Болбол}

Болгарская исламская академия, г. Болгар, Российская Федерация

ORCID: https://orcid.org/0000-0002-6642-5381,e-mail:bulbul.ismail@mail.ru

Резюме: статья посвящена мусульманскому взгляду на роль чтения в жизни человека. Автор анализирует теологические воззрения на данный навык, делая акцент на том, что чтение открывает человеку «дверь познания». Знание и его границы является одной из важнейших категорий мусульманской эпистемологии. Поэтому автор рассматривает феномен чтения и его важность в освоении таких дисциплин, как языкознание и литература, риторика. Адекватное понимание исходного текста реципиентом не является данностью. Автор специально останавливается на проблемах их возникновения и способах устранения. На этот счет статья содержит конкретные рекомендации.

Ключевые слова: Коран; наука о языке; риторика; Сунна; чтение

Для цитирования: Болбол И. Х. М. Феномен чтения и знание. Minbar. Islamic Studies. 2019;12(2):540-556. (На араб. яз.) DOI: 10.31162/2618-9569-2019-12-2-540-556.

$$
\begin{aligned}
& \text { القراءة تحويل الرمز المكتوب إلى رمز منطوق، أو تحويل الرمز المخطوط إلى رمز مسموع، } \\
& \text { بمعنى تفجير الطاقة الكامنة في الرمز الكتابي الصامت ليتحول إلى حركة ذهنية توحي بالمعاني } \\
& \text { المقارنة. }
\end{aligned}
$$

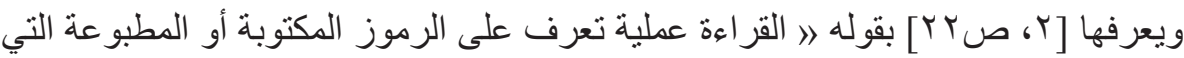

$$
\begin{aligned}
& \text { تستدعي معاني تكونت من خلال الخبرة السابقة للقارئ. }
\end{aligned}
$$

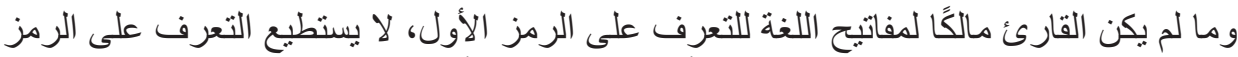

$$
\begin{aligned}
& \text { الثاني الذي يقوده إلى الدلالة، كما يحدث لأحدنا عندما يقف أمام كتابة لا يعرف لإن حروفها. }
\end{aligned}
$$

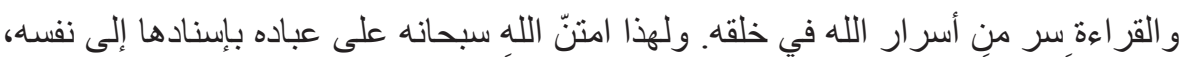

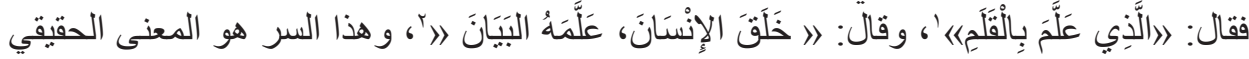

$$
\begin{aligned}
& \text { 1 } 1 \text { (العلق: } 4 .
\end{aligned}
$$

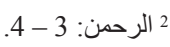


الدال على إنسانية الإنسان. ولو لاه لم يتحقق التكليف أو التبليغ الذي يصل الإنسان بربه، ويميزه

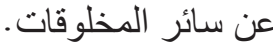

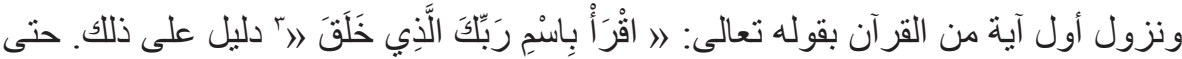

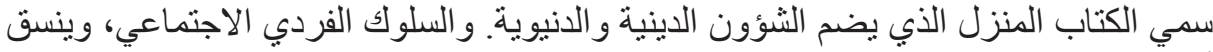

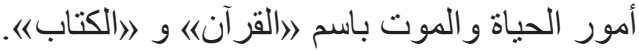

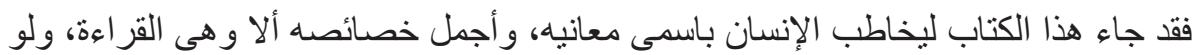
أنصف المناطقة في تعريف الإنسان لقالوا: الإنسان الإنسان مخلوق قارئ 》، بدل قولهم حيوان ناطق )؛.

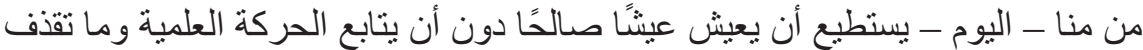

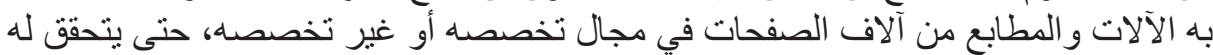

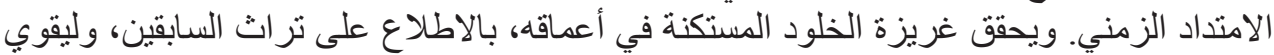
ارتباطه بجذوره و أصوله الزئ

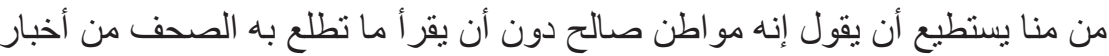

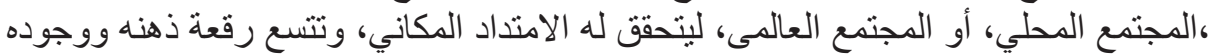

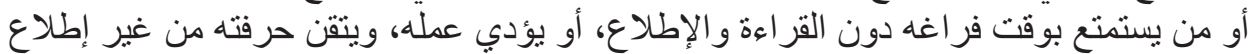

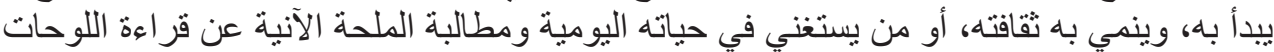

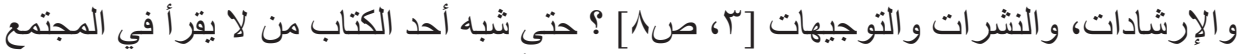

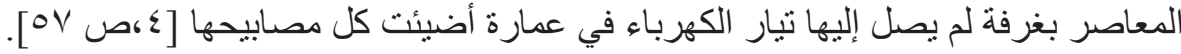

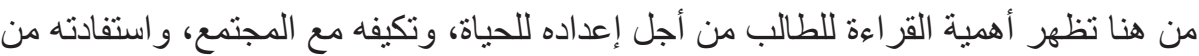

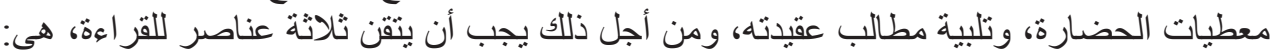

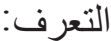
وهو الاستجابة البصرية لما هو مكتوب.

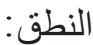
وهو تحويل الرموز المكتوبة أو المطبو عة التي تمت رؤيتها إلى أصوات ذات معنى.

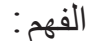

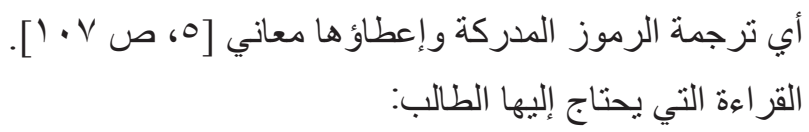

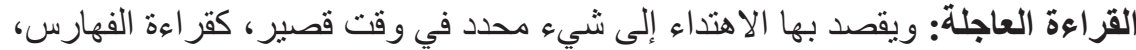

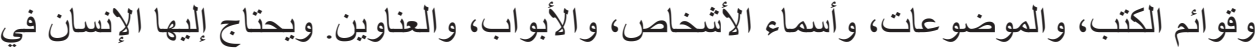

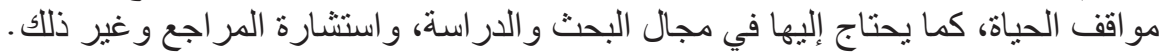




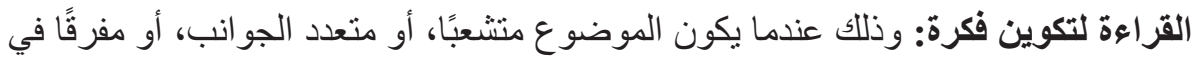

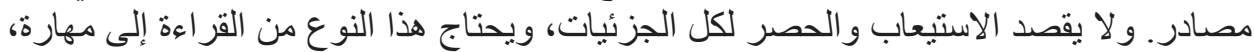

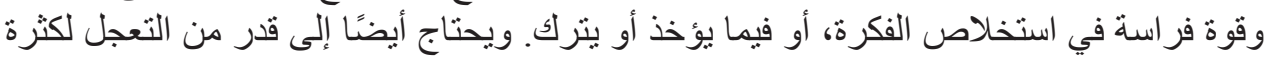
مصادر المعرفة في العصر الحديث.

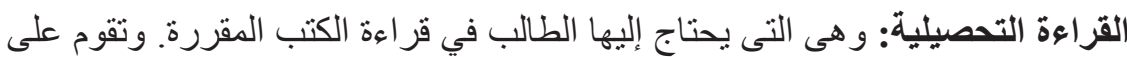

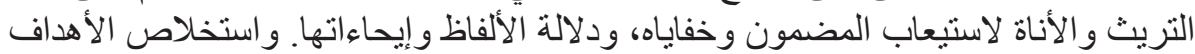

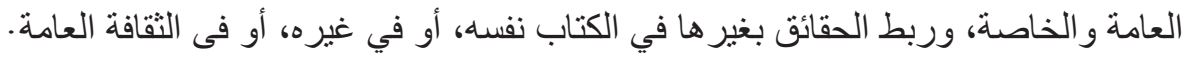

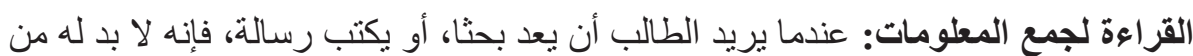

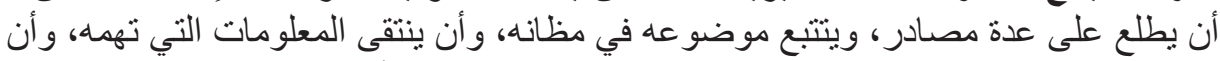

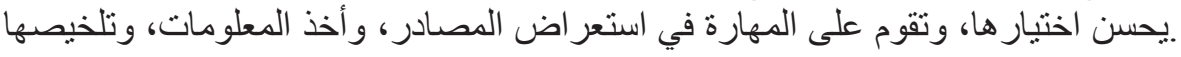

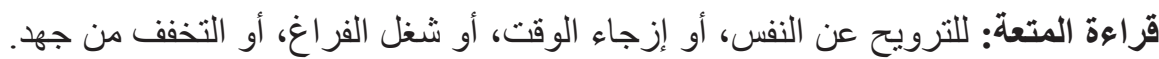

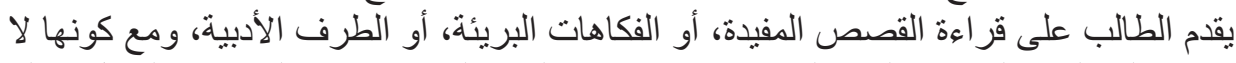

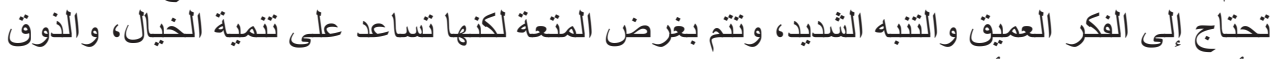
الأدبي، و التمرس بالأساليب الر اقية.

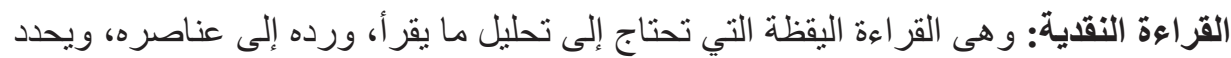

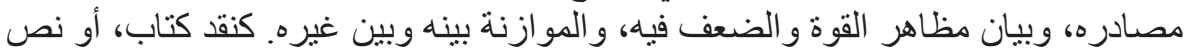
أدبى، أو قصيدة شعرية. و لا يتم ذلك بالتعجل و الاقتضاب. ولكن ولكن في ظل التأني و النظر، و و استشارة

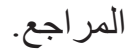

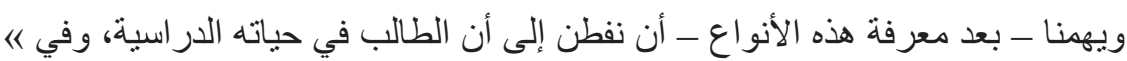

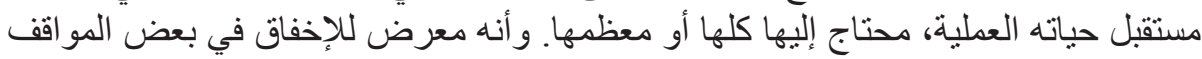

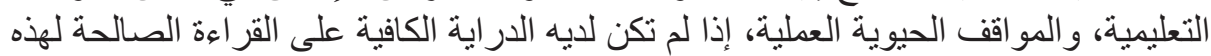

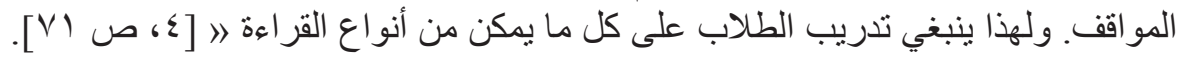

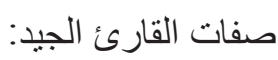

الذي يقر أ - جهرًا أو صمثًا - فيفهم المعاني التي تتضمنها المادة المكتوبة، ويستو عب ما فيها من أفكار.

الذي يقر أ - جهرًا أو صدنًا - فيفكر فيما يقر أ. ويمزجه بخبر اته السابقة، وبذلك بخرج من هن

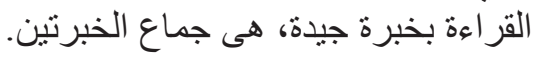

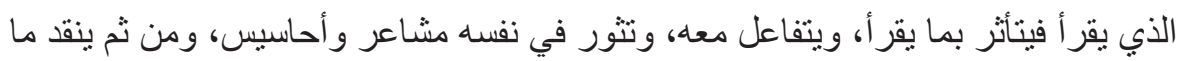

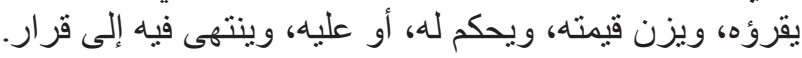

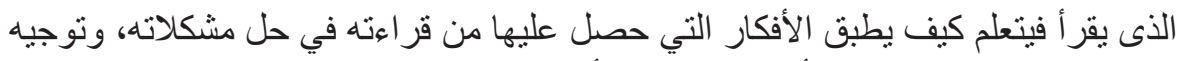

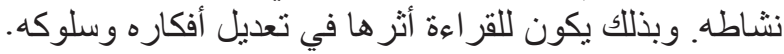

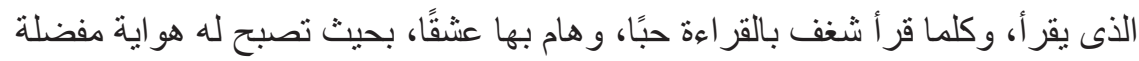

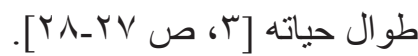


الذى يقرأ، فتظهر عنده جودة النطق، وحسن الأداء، وتمثيل المعنى.

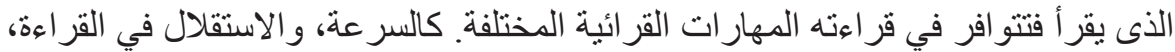

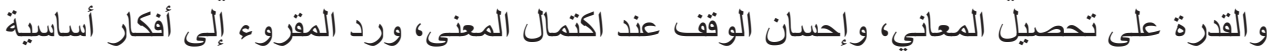

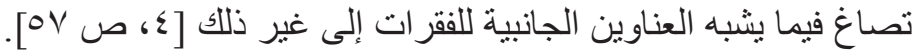

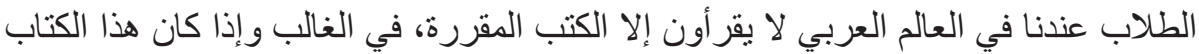

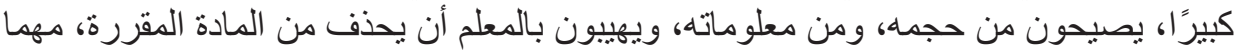
كانت قصيرة أو محددة.

فإذا تخرج أحدهم، و التحق بعمل، لم يعد يفكر في الكتاب، و انقطعت الصلة بينه وبين هذا المصدر المهم للمعرفة. و أكثرنا تتكون لديه خبرة سيئة عن الكتاب، يترتب علئ عليها النفور و العداء، ويوصف الكتاب بأوصاف التهكم والسخرية.

و المفروض أن تكون العلاقة صداقة وقربى حميمة، وليس الإنترنت أو الكتاب الإلكتروني بكاب بأحسن حالاً من الكتاب الورقي.

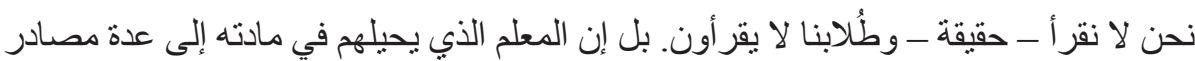

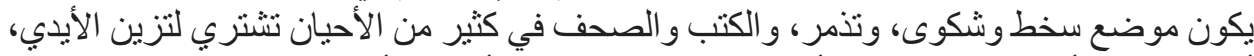

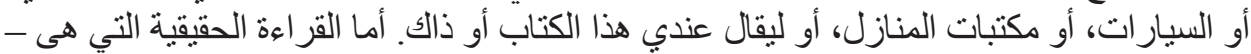

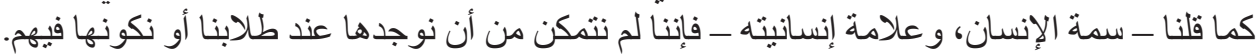

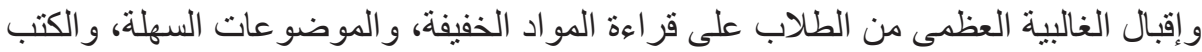

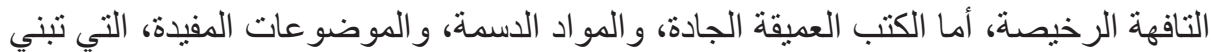
العقل و الثخصية، فنصيبها نادر .. نادر.

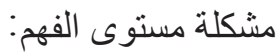

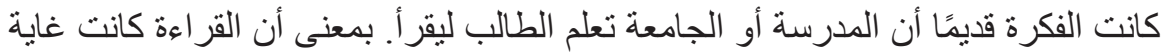

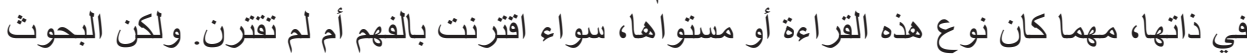

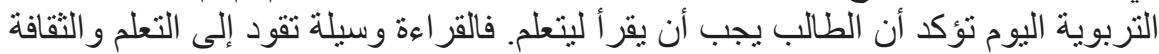

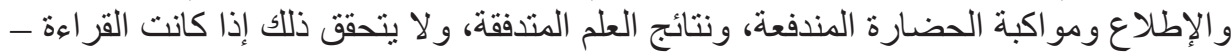

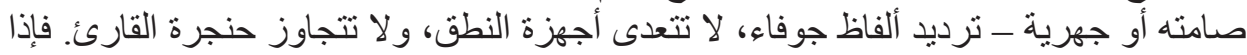

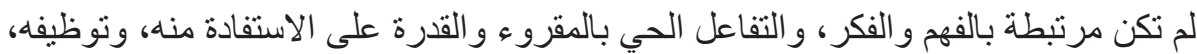
فلبست قر اهة.

وتقر التربية الحديثة بهذا التطور لمفهوم القراعة، وهذا ما يجمع عليه الحس العام لمدلول

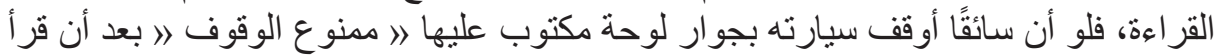

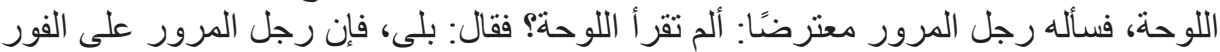

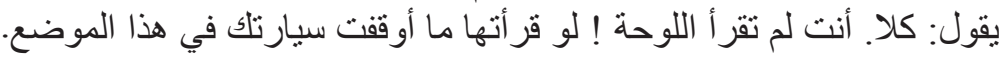

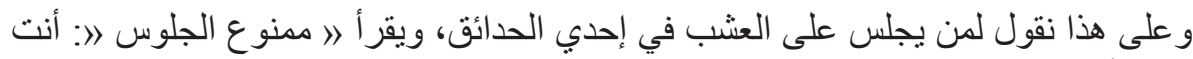

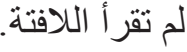


معنى ذلك: ارتباط القراءة بالفهم و العمل. وبغير ذلك تكون القر اءة أصو اثتًا ليس لها مضمون،

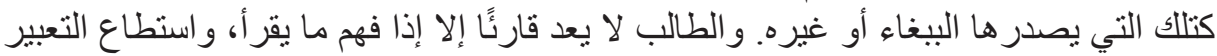

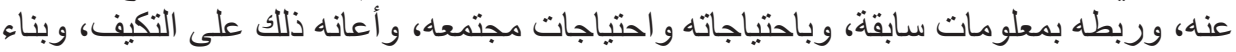

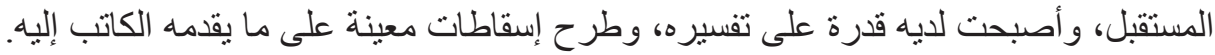

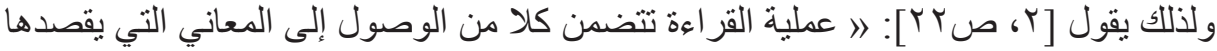
الكاتب، و إسهام القارئ نفسه في صياغة تفسير هذه المعاني، وتقديمها و انعكاساتها.

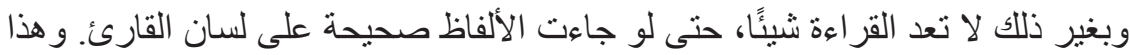

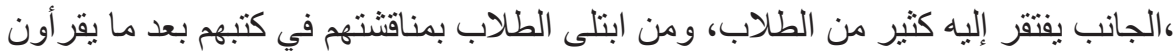

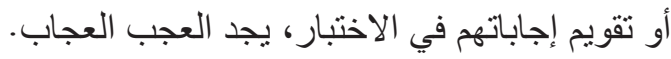

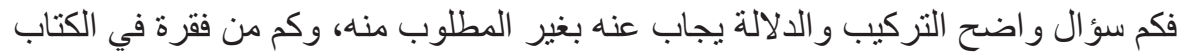

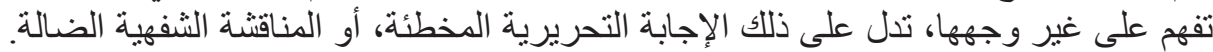

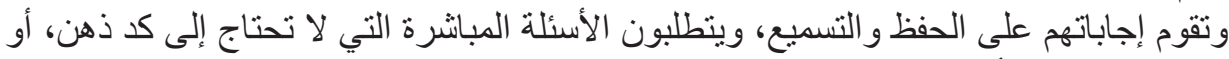

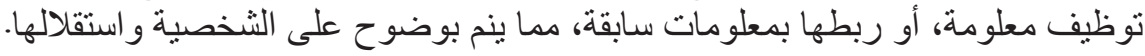

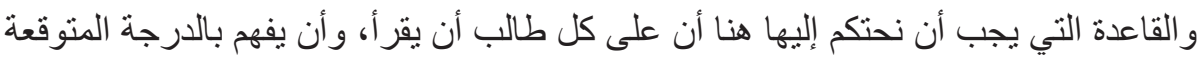

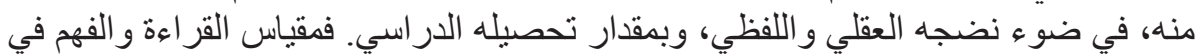

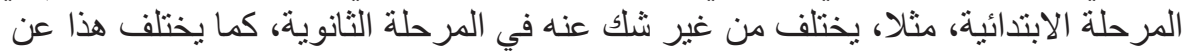

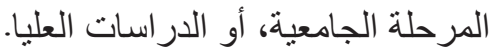

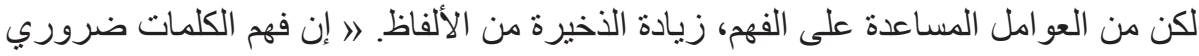

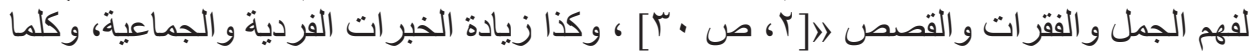
كان مستوى الفرد، ومستوى الجماعة متقدمًا، وجو انب الحياة الفردية و الجماعية متنو عةد، و وعميقة، كانت القدرة على الفهم و التفاعل أقوى.

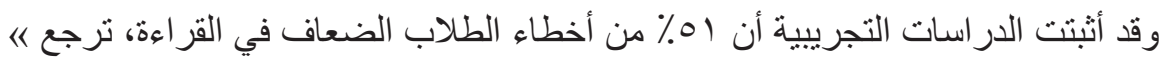

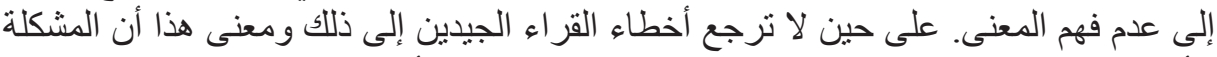

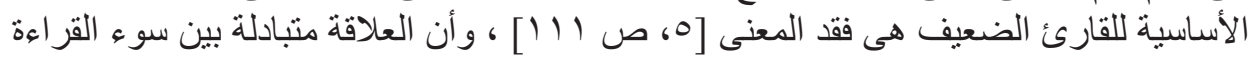

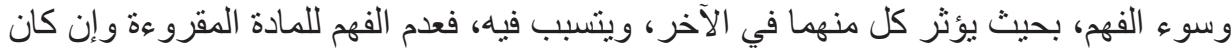

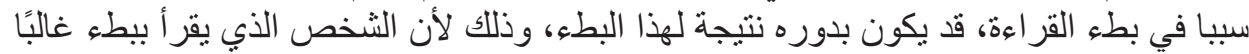

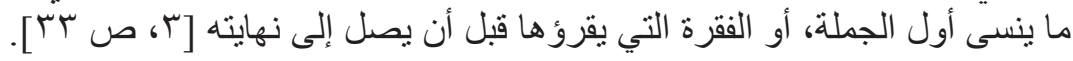

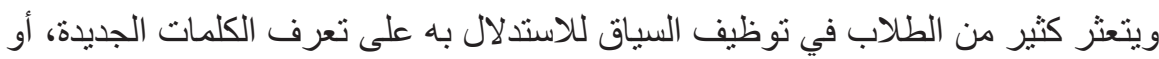

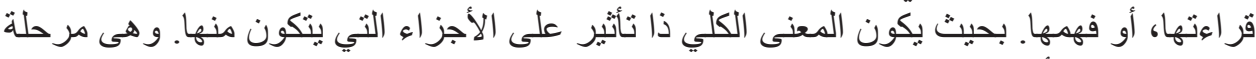

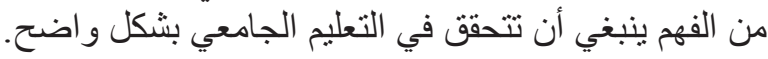

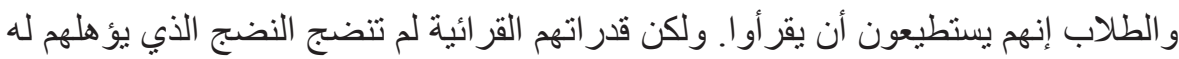

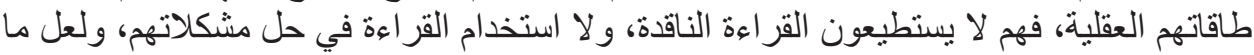
يعانيه الكثيرون من التخلف في ميادين العيش، يرجع إلى عجز تحصيله التهم القرائي أكثر مما يرجع إلى ضعف في قدر اتهم العقلية. 


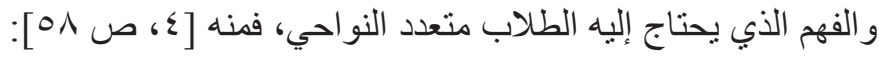
الفهم لكسب المعلومات وزيادة الثقافة و المعرفة. كقر اءة الكتب العملية و الدر اسية و الصحف

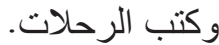
الانتفاع بالمقروء في الحياة العملية كقر اعة الخطابات، و الإعلانات و التعميمات، و النشر ات، و اللافتات، وجداول الأمتحانات. المتعة و التسلية و التذوق كقر اعة القصص، و الفكاهات، و الطر ائف، و الثُعر. نقد الموضو عات كقر اءة الصحف، أو الكتب، أو البحوث لنقدها و التعليق عليها. ويمكن أن نضيف نوعًا آخر من الفهم. وهو الفهم الدراسي من أجل نمو الثخصية العلمية، واجتياز الامتحان، ولكن لا ليكون الامتحان غاية، بل وسيلة إلى توظيف المعلومات، وربط فئ بعضها إلى بعض، و استخلاص النتائج.

و هذه الأغر اض تختلف في نو عها، و اتساعها، و عمقها، باختلاف مر احل التعليم و أهدافها،

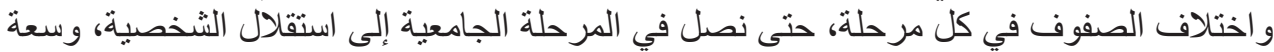
الاطلاع، و البحث العلمي.

مشكلة نوع الإلقاء: الإلقاء فن متعلق بطر ائق الإبانة الكلامية. ويعني خاصة بالإخر اج الصوني للنصوص. ويتحقق ذلك بعدة أمور. إعطاء كل حرف أو لفظ حقه كاملاً من التعبير الصوتي. تحميل العبارة إحساسات و عو اطف مناسبة لمضمونها، بحيث يكون أثز ها بليغا في نفس السامع ·

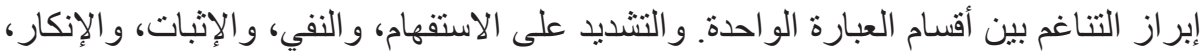

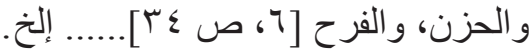
ولقراءة أي نص شعري أو نثري، أو فقرة من كتاب، أو مقطع من مقالة أو جزء من بحث،

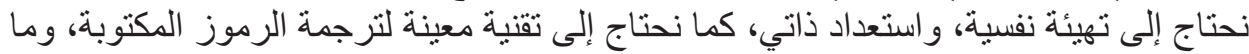
تضم من إحساسات، وتوصيلها إلى المستمع. تصن. و ما لم يقترن ذلك بجودة النطق، وحسن الأداء، ووضوح المخارج، و التكيف مع المعنى،

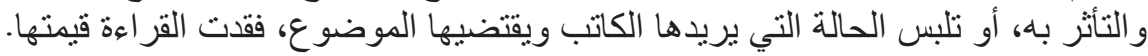
و الملحوظ أن هذا الجانب يفتقر إلبه كثير من الطلاب، فهم لا يملكون آليات القراءة الجيدة،

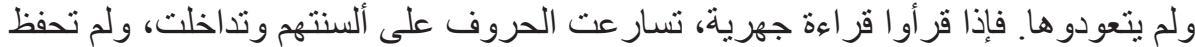

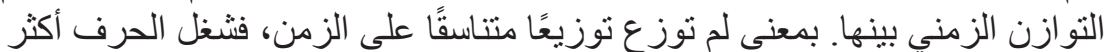
أو أقل مما يستحق، ووقعت فجوات بين المقاطع و الحروف، كما أن مخارج الحروف لان لا تستقر في 
أماكنها تمامًا، ولكنها تتر امي في مو اضع قريبة منها، أو من جار اتها، متأثرة بالعامية.

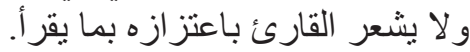

و هناك الكثيرون من البالغين الذين لا يحبون أن يقوموا بالقر اءة الجهرية. وربما كان ذللك راجعًا

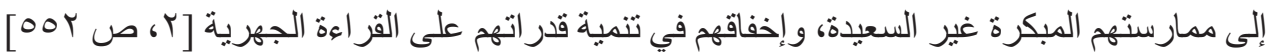

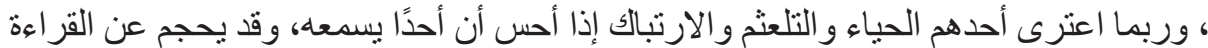

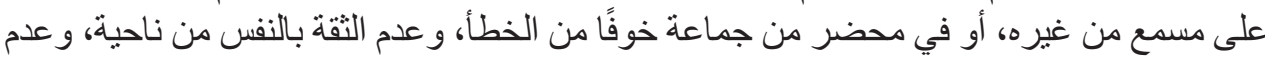

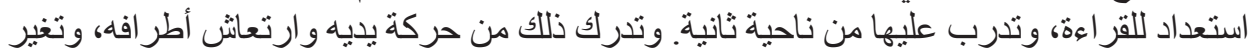

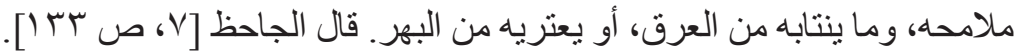

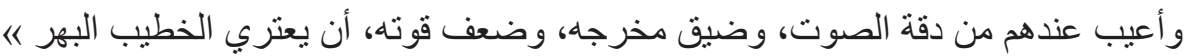

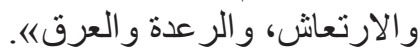

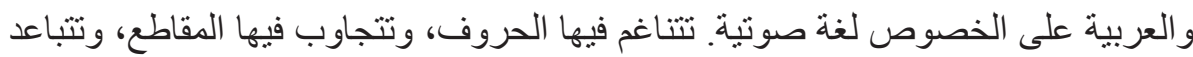

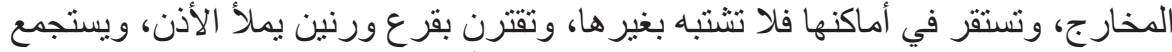

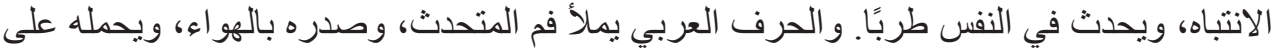

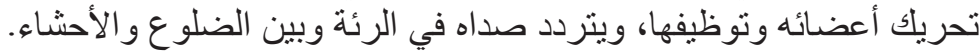

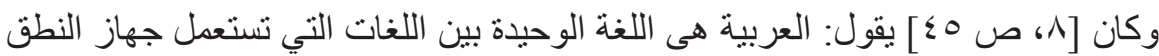
بكل عناصره وطاقته.

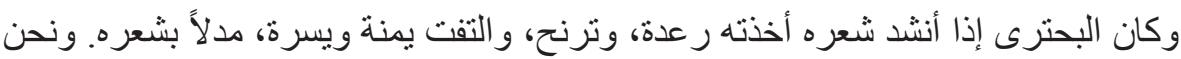

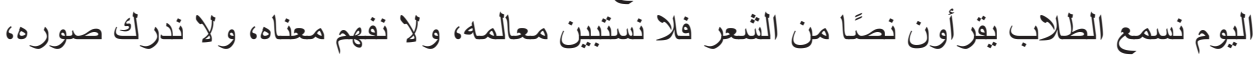

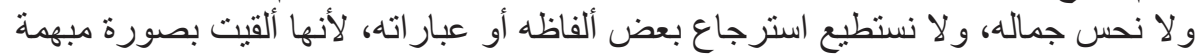

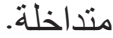

و أكثر ما تظهر هذه الصورة عندما يكون النص محفوظًا، ويريد الطالب تسميعه، فإن ألفاظه

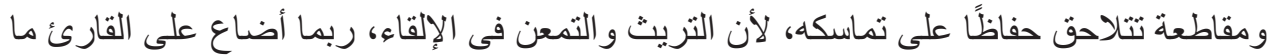
حفظ، لهذا تهر قيمة الإلقاء وتمثنيل المعنى.

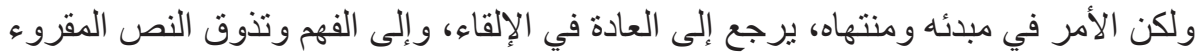

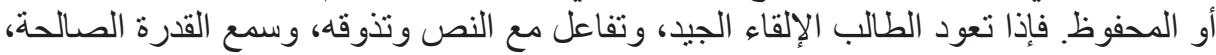

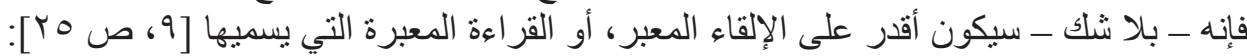

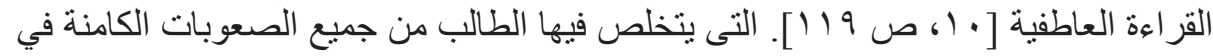

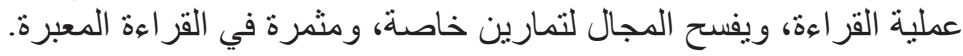

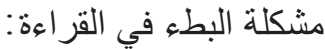

تعد السر عة في القر اعة إحدى المهار ات التي يتم التدريب عليها، وتتوخاها التربية الحديثة.

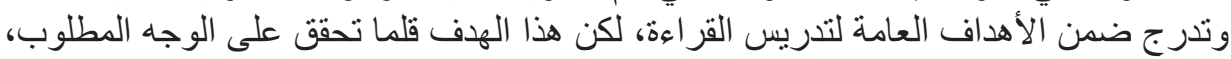

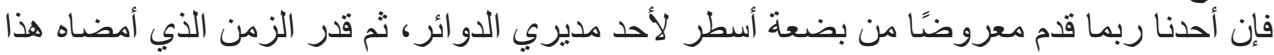

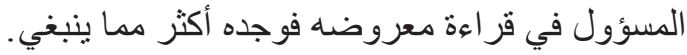




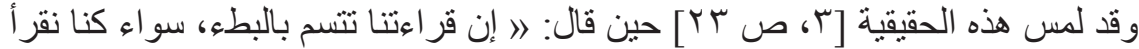

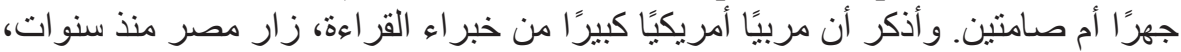

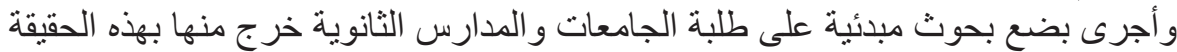

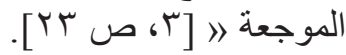

وفي رأيي أن القضية تتجاوز اتهام اللغة العربية بالصعوبة الذي اعتداندا سماعها، كما تتجاوز

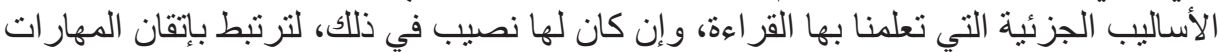

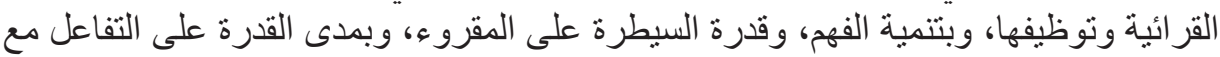

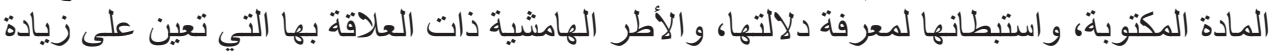

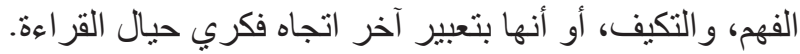

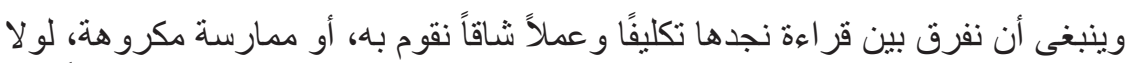

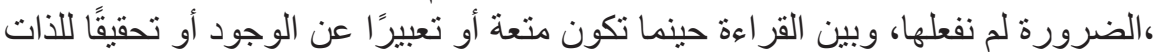

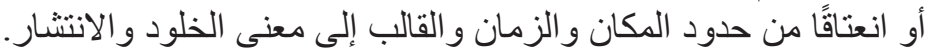

وتزداد حاجة طلابنا اليوم إلى القراءة في هذا العصر الذي تفجرت فيه المعرفة، وتدفقت

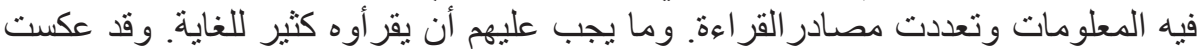

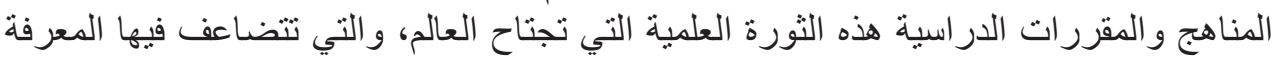

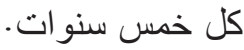

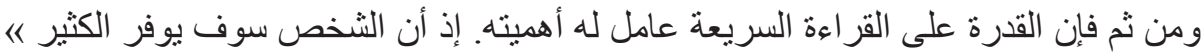

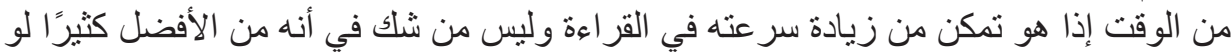

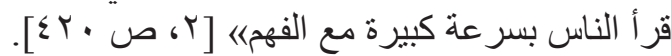

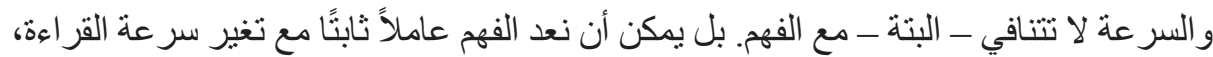

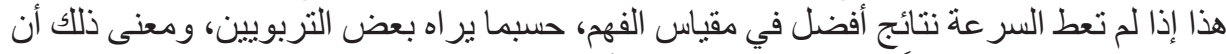

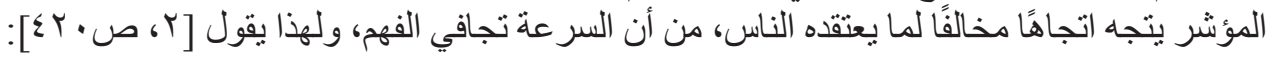

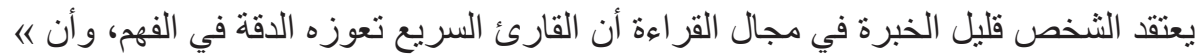

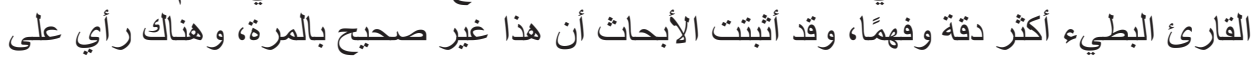

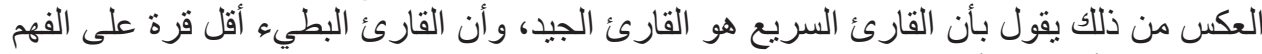

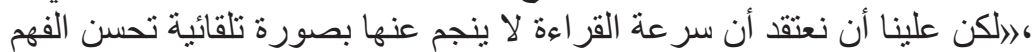

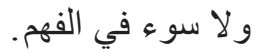

ولهذا البطء أسباب تعود إلى قلة إتقان مهار ات القر اءة الأساسية، ويمكن تحليلها في: الإسر اف في تفرس وتعمق المقروء.

بطء الحركة الذهنية عند القارئ، بحيث لا تو اكب حركة العين. فتضطر العين إلى التراجع و الانتظار.

الإسر اف في تحليل الكلمات البصرية المعروفة، أو تقسيم الكلمات إلى أجزاء كثيرة تشغل القارئ عن الانطلاق وسر عة القراءة. 
عدم القدرة على القر اءة في وحدات فكرية، بحيث يتم التعرف بنظرة واحدة على مجمو عة من الكلمات تمثل وحدة في الفكر و المنطق.

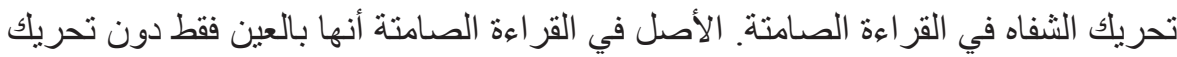

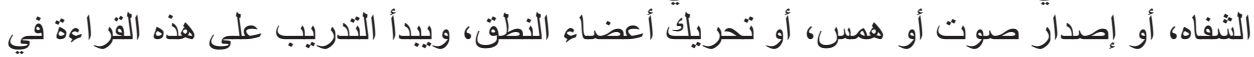

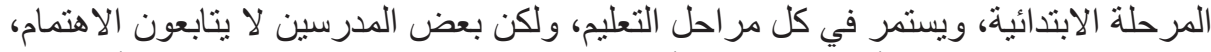

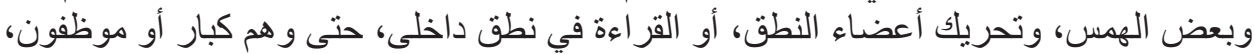

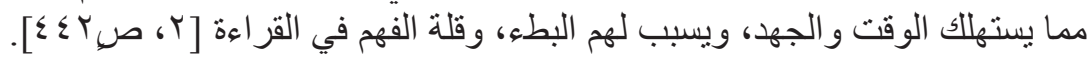

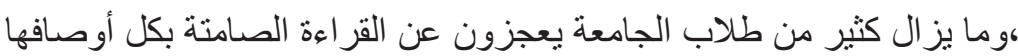

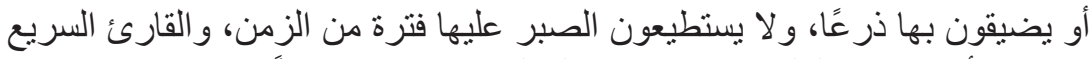

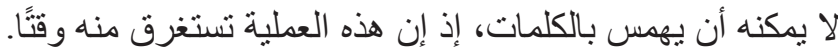

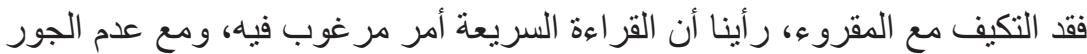

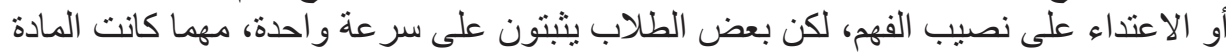

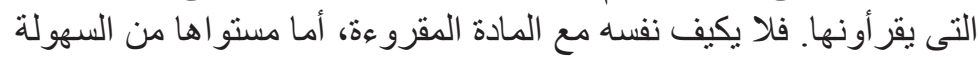

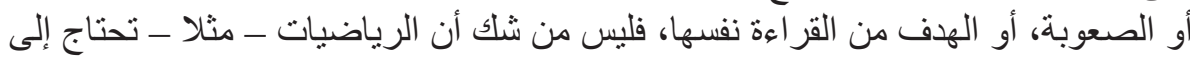

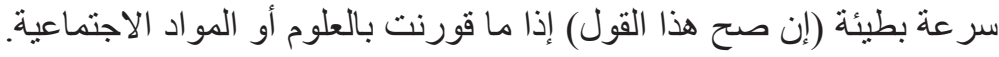

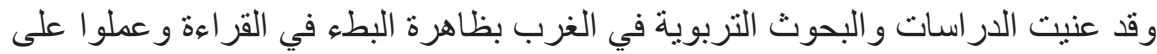

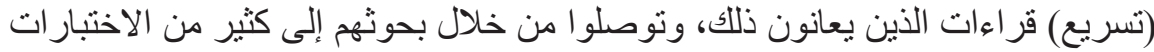

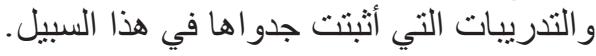

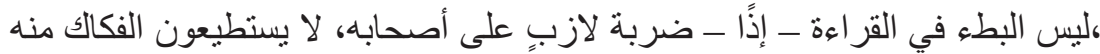

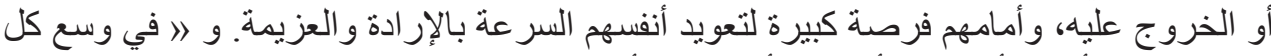

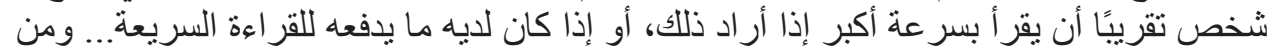

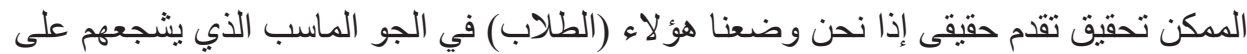

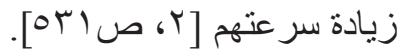
أسباب أخطاء الطلاب في القر اءة عن:

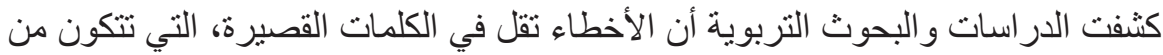

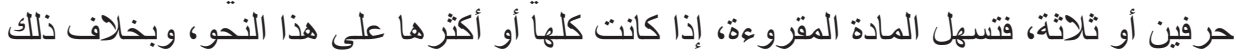

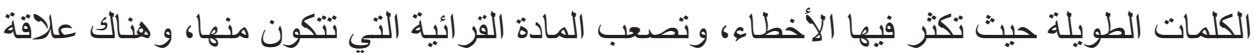
وطيدة ومطردة بين حجم الكلمة و عدد حروفها وبين احتمال وقوع ولهو الخطأ فيها.

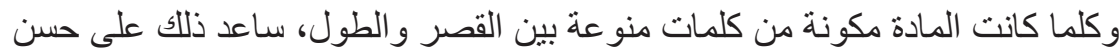

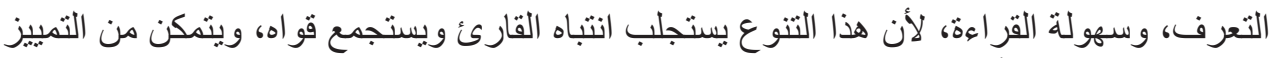
بين الكلمات، فتقل الأخطاء في قر اءتها.

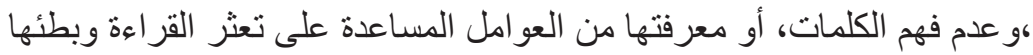

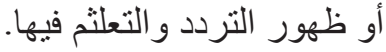




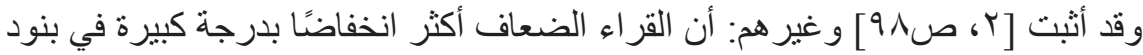
المفردات في اختبار ستانفورد وبينيه للذكاء من القر اء الجيدين الذين الذين بعادلونهم في مستوى الذكاء.

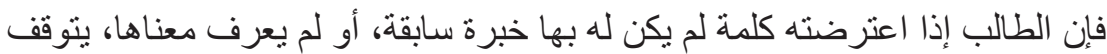

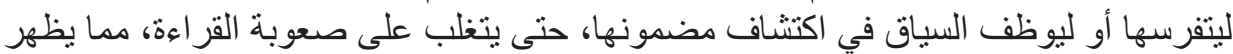

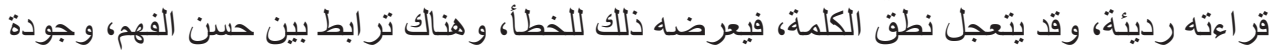

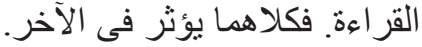

وقد بينت الدر اسات التي أجريت لتحديد أنو اع الأخطاء التي يقع فيها الطلاب الضعاف، ما يأتى: أخطاء سببها التشابه بين الكلمة المكتوبة و الكلمة التي حلت محلها في الخطأ، أو استبدلت بها، وتبلغ نسبة شيوع هذا النوع من الأخطاء 7 (1\% من مجموع الخطاء الخطاء التعرف.

أخطاء ترجع إلى التماثل في الحرف الأول بين الكلمات الأصلية و الكلمة التي استجلبها

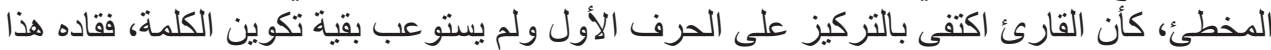

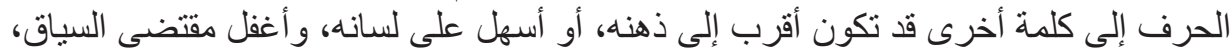

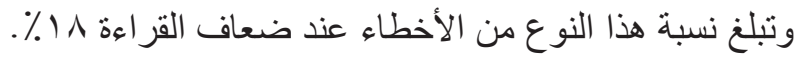

أخطاء مردها إلى تماثل الحرف الأخير بين الكلمة الأصلية و الكلمة الجديدة التي حلت محلها،

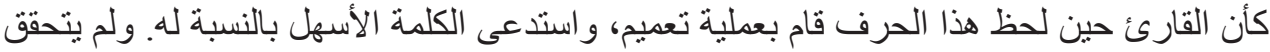

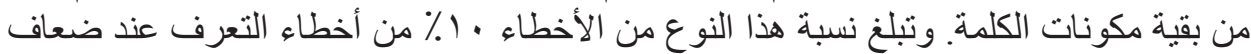

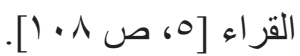
وليس من شك في أن الحالة الجسمية للطالب من العوامل المهمة في سلامة القر اءة أو وقوع الخطأ، ويظهر ذلك في الكي:

الصحة العامة: فالطالب الصحيح المعافي يكون أقدر على القراءة، وأبعد عن الأخطاء، بينما يكون الذليل الضعيف عُرضة للخلل والخطأ.

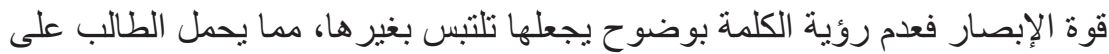

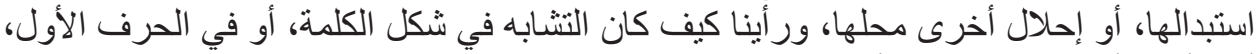
أو الأخير أسبابًا لوقو الخو الخطأ عند هذه الفئة من الطلاب.

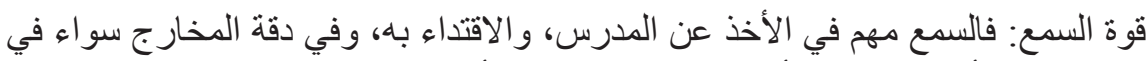

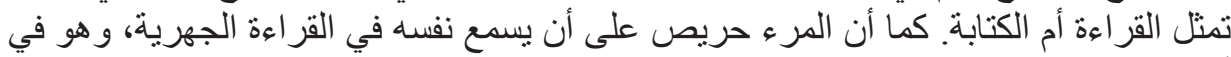

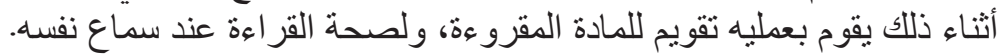
أنو اع الأخطاء في القراءة:

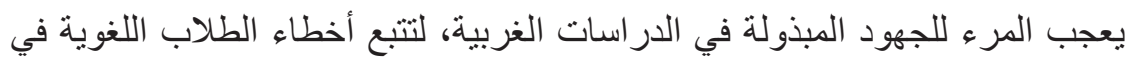

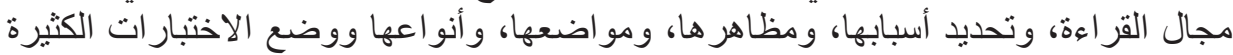
و المتنو عة لقياس ذللك. 
في الوقت الذي تكاد تقتصر جهود أبناء العربية على الترجمة و النقل، على الرغم من اختلاف

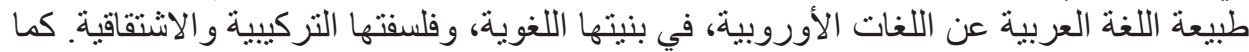

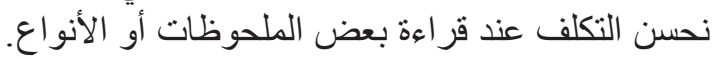

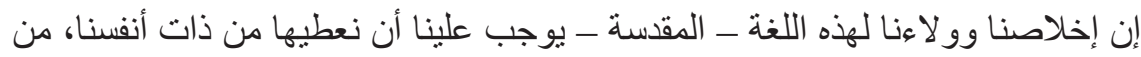

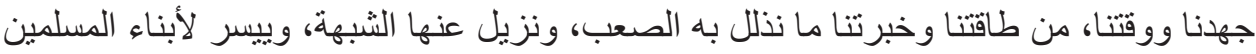
تعلمها و الإطلاع عليها.

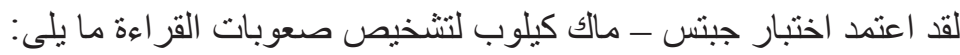

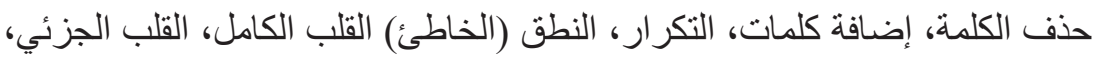

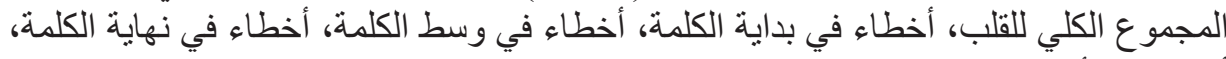

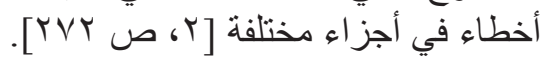

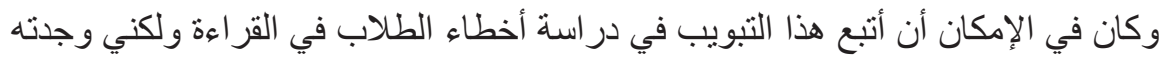

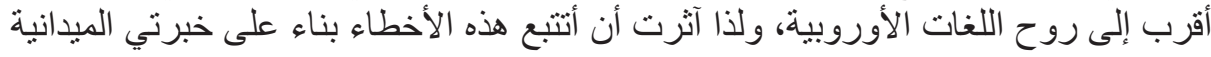

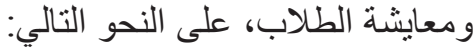

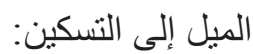

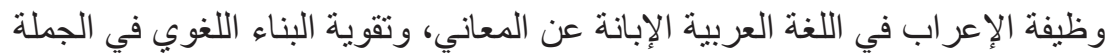

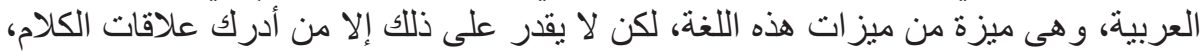

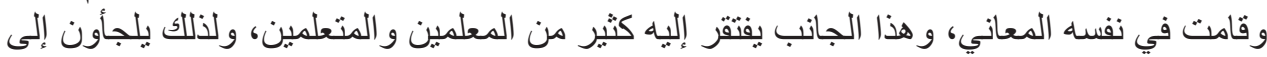

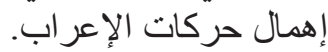

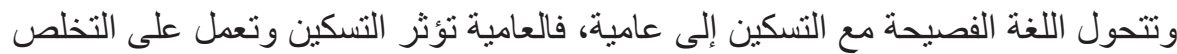

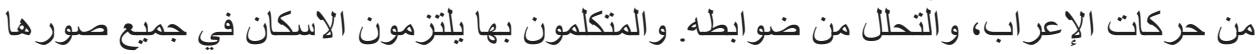

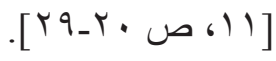

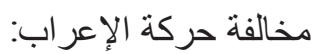

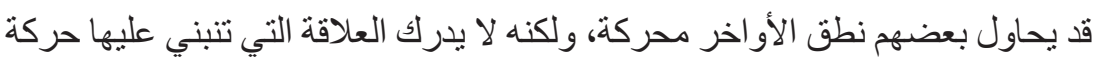

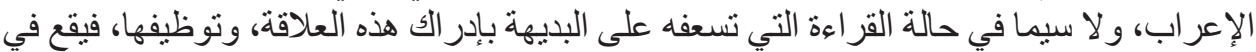

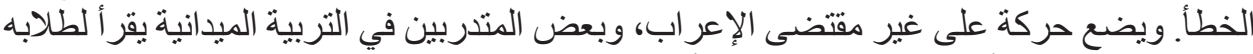

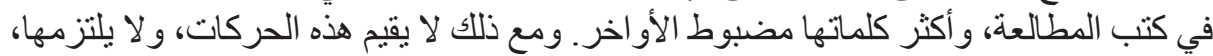

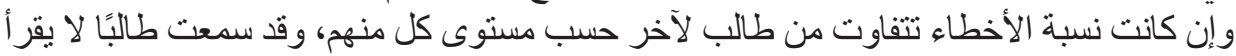

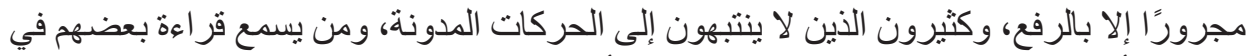

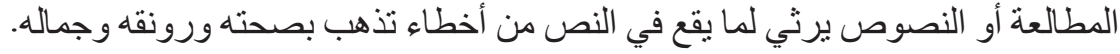
نصب المفرد المختوم بالألف و التناء بالكسرة:

لثبهه بجمع المؤنت السالم، مثل: مبار اة، ومحاكاة، ومر اعاة، ومساو اة. و ولا سيما إذا أضيف

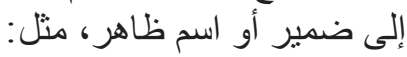


لعبو ا مبار اتهم بمهارة ـ كر هت محاكاتهم لأعدائهم - حمدت مر اعاتهم للنظام - إن مساو اة

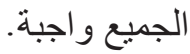
ويدخل في ذلك كلمات مثل: أبيات، وأشتات، وسبات، و هنات. لكونها مختومة بالألف و التاء. وسمعت أُحدهم يقر أ: على المرضى أن يتناولو ا أدويتهم حسب ارشنادات الطبيب.

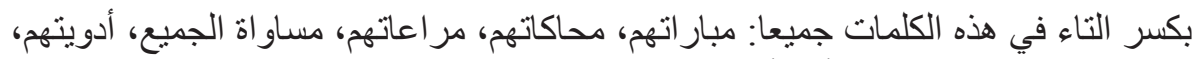
و إنما هى منصوبة بالفتحة لأنها أسماء مفردة. قطع همزة الوصل في القراءة و الحديث، فى مثل: اكتب، اسكت، انتبه، استخرج، يوم الاثثين.

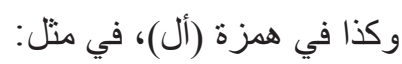
مسرح المدرسة، كتاب الولد، أسئلة الامتحان، ورد الحديقة، ويظهر التأثر بالعامية بوضوح

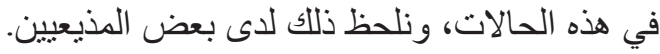

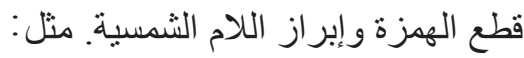
ركبت السيارة - وقابلت الضيوف ــ الزر افة عنقها طويل. و أكثر ما يظهر ذلك عند إر ادة الكتابة أو الإملاء على الآخرين خشية الوقوع في الخطأ لكنها على كل حال أقل وضوحًا، و أقل انتشارًا من سابقتها. عدم تحكيم قو اعد الدمج (الحذف): إذا سبق (أل) حرف من حروف المد، مثل. في - الصباح، في - المدرسة.

وتظهر هذه المدود بسبب الرغبة في قطع الهمزة. فيترنب على ذللك إنباع المد، وحقه أن يكون قصرًا (كما هو في الوزن العرد العروضيب). إنشباع الحركات في وسط الكلمة:

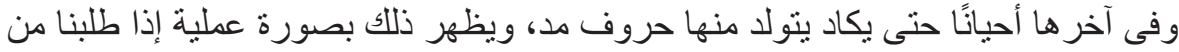

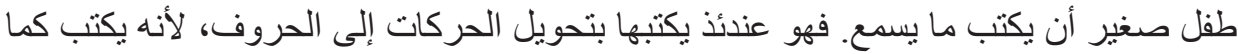

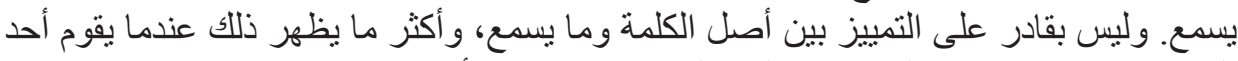
المتدربين بإملاء قطعة على تلاميذ المرحلة الابتدائية. فقد رائ بعضي بعضهم يكتب.

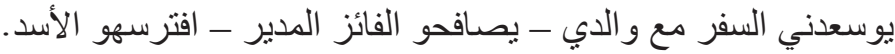
وذللك لأن الحركة استغرقت زمنا أكثر مما تقتضيه، فأوحت إلى بعض التنلاميذ أنها حرف مد.

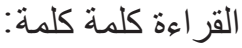




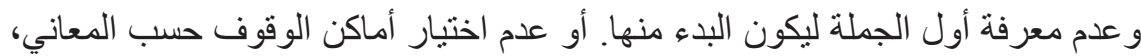

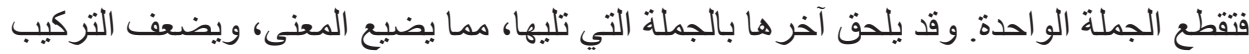

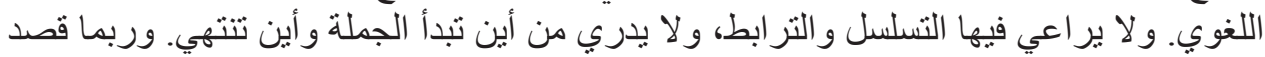

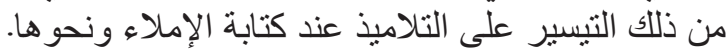
عدم التعبير عن معاني علامات الترقيم: مانير

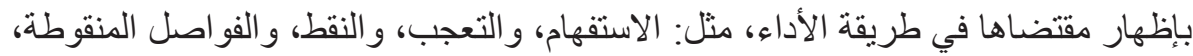
و الفو اصل غير المنقوطة، والأقواس، و علامات التنصنيص، و غيرها.

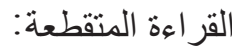

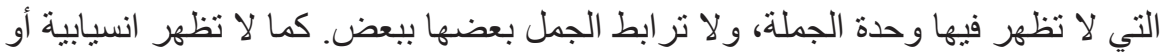

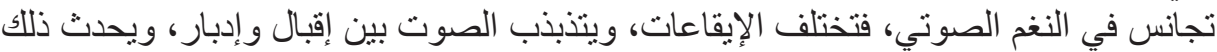

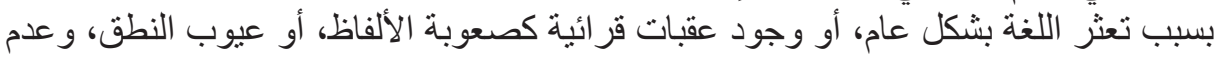
توظيف علامات الترقيم، وفهم مدلو لاتها. تكر ار الكلمة الواحدة.

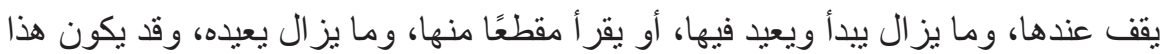

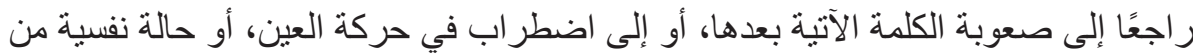

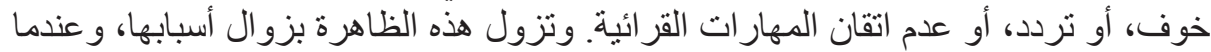
تكون المادة المقرو تُوة أكثر سهولة. صرف الممنوع من الصرف لعدم معرفة حالاته: وترجيح التتوين بناء على تعميم الأحكام أو الأكثرية. و أكثر ما يظهر ذلانه فئل في حالة الرفع. لأن

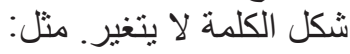

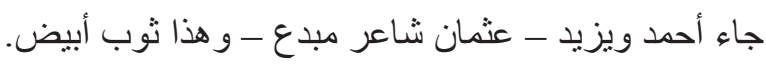

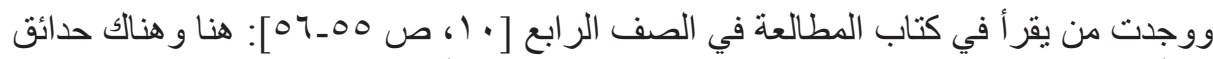

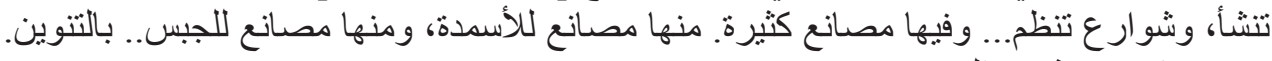

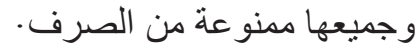

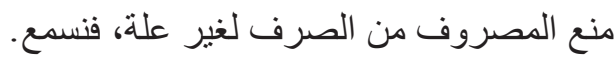
خالد ولد مؤدب - سامر تلميذ مجتهد - سامح قال للمعلم - نجح حازم في الامتحان. ونثير هنا إلى بعض أساليب العلاج: التأكد من حسن أداء الأعضاء الصوتية لهنية والسمعية و البصرية:

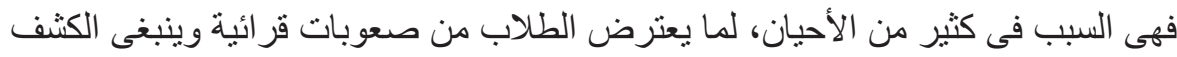

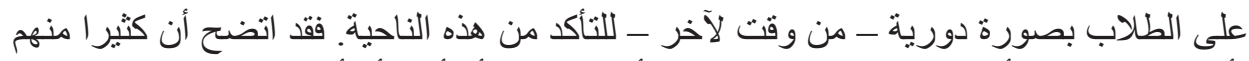
يأفف من الحقيقة، أو يستحيي من لبس النظارة أمام زملائه أو أهله أو أفر اد المجتمع. 


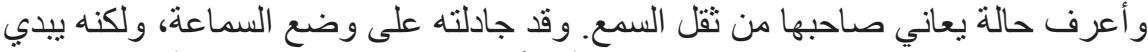

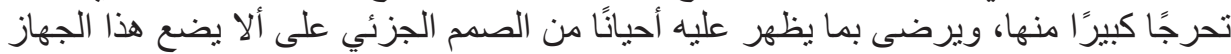
الصغير الذي لا يكاد يلتفت إليه أحد. النحو العلاجي: - الني:

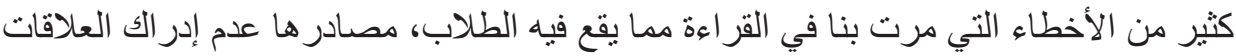

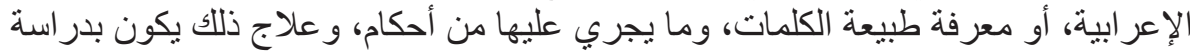

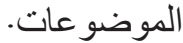

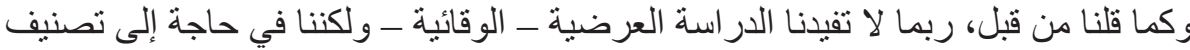

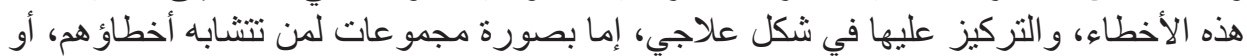
بصورة فردية مع الأساتذة المتخصصين.

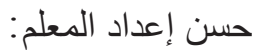

في كل مر احل التعليم، حتى يكون قدوة لطلابه في القراءة الصحيحة الموقعة. وليكتسب منه إنها

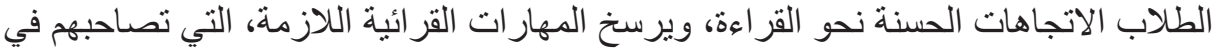

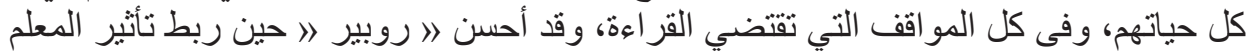

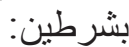

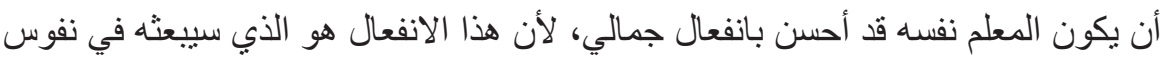
تلاميذه. إذ يجعله يتفجر نوعًا ما بو اسطة الأسئلة.

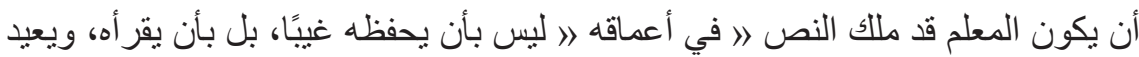

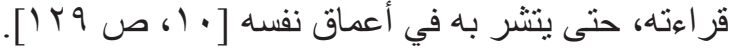

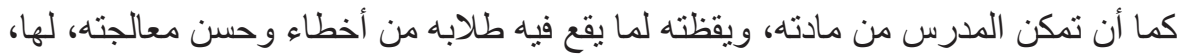

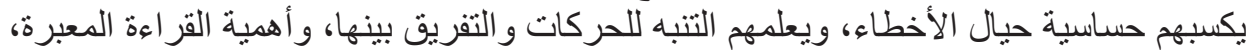

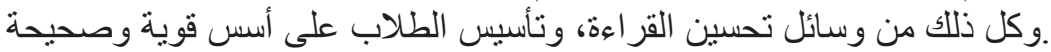

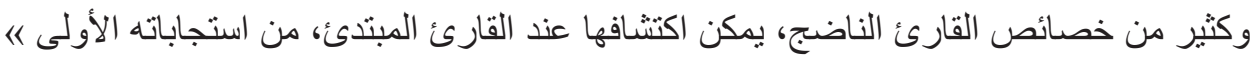

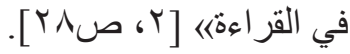

وحبذا وجود حصة أو أكثر للمطالعة في كل أقسام المرحلة الثانوية، أسوة بالقسم الأدبي، وكذا في أقسام اللغة العربية بالكليات. زيادة استخدام الأجهزة و الوسائل التعليمية.

كالأشرطة و أفلام الفيديو التي تضم نماذج من القر اءة الجيدة المؤثرة، والإلقاء المعبر.

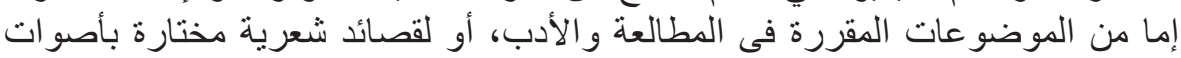

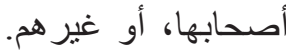

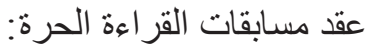


ومسابقات الإلقاء. وتنتشيط هذا الجانب التراثي، الذي يكاد يهمل في هذا العصر، فكم لحلقات

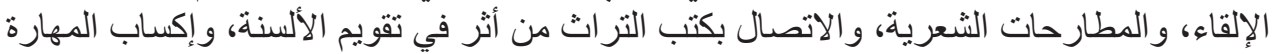

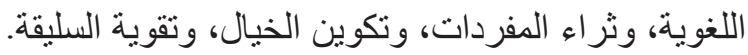

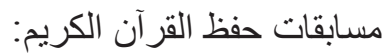

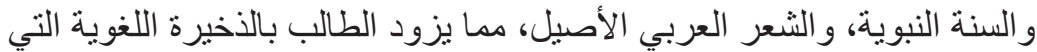

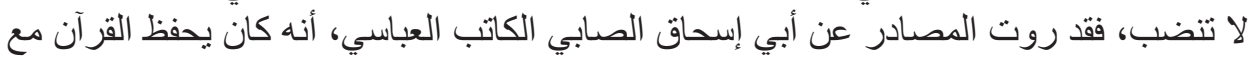

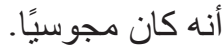

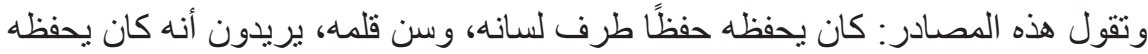

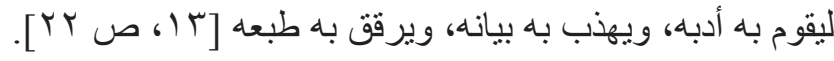
اختيار المادة القر ائية المناسبة لكل مستوى: فإن الإخفاق في تكييف المو اد و الطرق، في تعليم القراءة، لمدى القدرة القرائية، الموجود في لئي

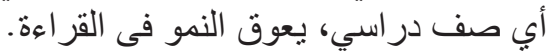

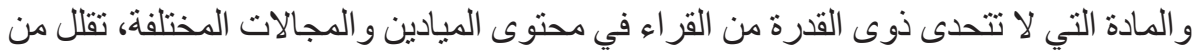

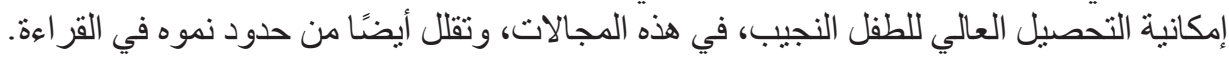

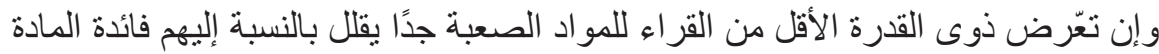

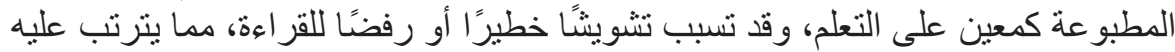

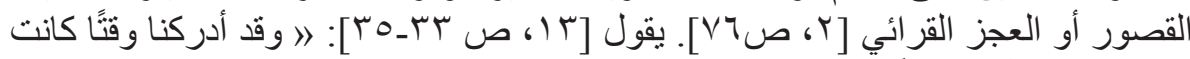

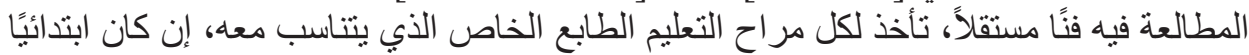

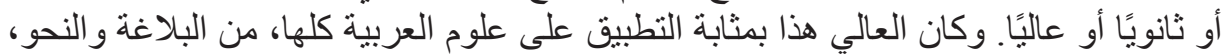

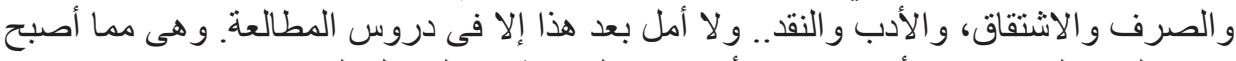

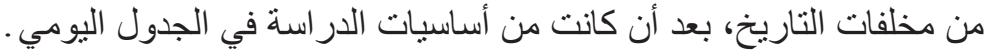

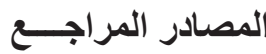

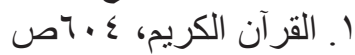

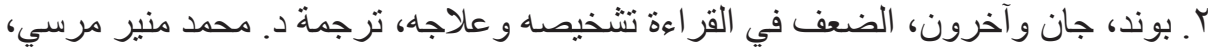

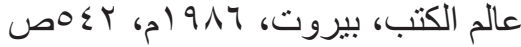

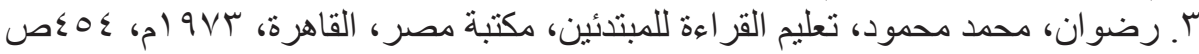

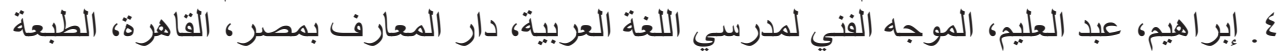

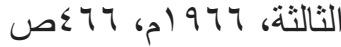

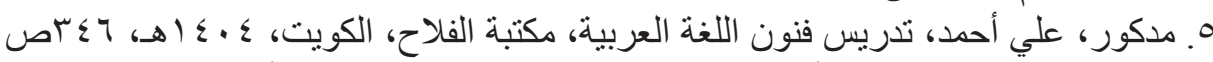

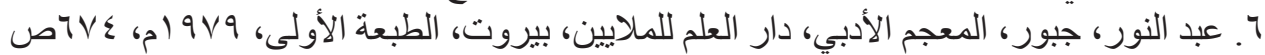

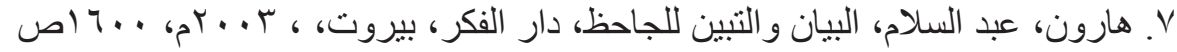

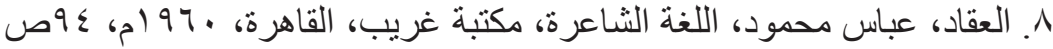


9. روبير، دوتر انس، التربية والتعليم، ترجمة دز هشام نشابة و آخرين، مكتبة لبنان، بيروت،

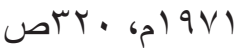
• ا ـ ظافر، محمد إسماعيل، القر اءة و المحفوظات، وزارة التربية والتعليم، الرياض، الطبعة

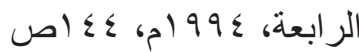

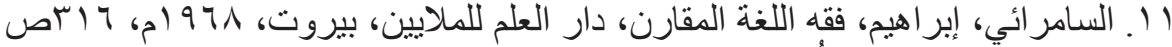

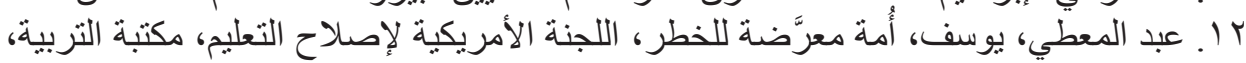

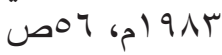
T1 أبو الخشب، إبر اهيم علي، محنة اللغة العربية، مكتبة الأنجلو المصرية، القاهرة، 9VV (م، ع ـص

$$
\text { معلومات عن المؤلف }
$$

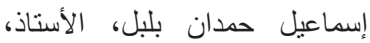

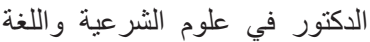

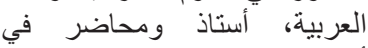
أكاديمية بلغار الإسلامية في روسيا الاتحادية

\section{Information about the author} Ismail H. M. Bolbol, Ph. D (Islamic Sciences and Arabic), professor, lecturer of Muslim religious organization of spiritual educational organization of higher education «Bulgarian Islamic Academy», Bolgar, Russian Federation.

\section{Информация об авторе}

Исмаил Х. М. Болбол, Ph. D (исламские науки и арабский язык), профессор, преподаватель Мусульманской религиозной организации Духовная образовательная организация высшего образования «Болгарская исламская академия», г. Болгар, Российская Федерация.

\section{Conflicts of Interest Disclosure}

The author declares Conf-licts of Interest Disclosure.

\section{Article info}

Received: $\quad$ May 7, 2019

Reviewed: $\quad$ May 25, 2019

Accepted: $\quad$ May 27, 2019

\section{Раскрытие информации о конфликте интересов}

Автор заявляет об отсутствии конфликта интересов.

\section{Информация о статье}

Поступила в редакцию: 7 мая 2019 г.

Одобрена рецензентами: 25 мая 2019 г.

Принята к публикации: 27 мая 2019 г. 